\title{
Quality of Cabernet Sauvignon Wines Determined by the Variability of Climatic Attributes
}

\author{
Tiago Stein ${ }^{1}$, Ivan Ricardo Carvalho ${ }^{2}$, Vinícius Jardel Szareski ${ }^{2}$, Renata Gimenez Sampaio Zocche ${ }^{1}$, \\ Fernando Zocche ${ }^{1}$, Keila Garcia Aloy ${ }^{1}$, Lucas de Vargas dos Santos ${ }^{1}$, Hyoran Caius Genindo Barreto Martins ${ }^{1}$, \\ Francine Lautenchleger ${ }^{3} \&$ Velci Queiróz de Souza ${ }^{1}$ \\ ${ }^{1}$ Federal University of the Pampa, Dom Pedrito, Rio Grande do Sul, Brazil \\ ${ }^{2}$ Federal University of Pelotas, Capão do Leão, Rio Grande do Sul, Brazil \\ ${ }^{3}$ State University of Londrina, Paraná, Brazil \\ Correspondence: Fernando Zocche, Federal University of Pampa, 21 de Abril Street, $n^{\circ}$ 80, Zip Code 96450-000, \\ Dom Pedrito, Rio Grande do Sul, Brazil. E-mail: fernandozocche@unipampa.edu.br
}

Received: February 24, $2018 \quad$ Accepted: April 4, $2018 \quad$ Online Published: July 15, 2018

doi:10.5539/jas.v10n8p380 URL: https://doi.org/10.5539/jas.v10n8p380

\begin{abstract}
Essential to understand the dynamics responsible for the quality of red wines, the objective of revealing the physico-chemical and climatologic relationships that determine the quality of Cabernet Sauvignon wines. The experiment was carried out in the municipality of Dom Pedrito, Rio Grande do Sul, Brazil, in the agricultural crop of 2016. The experiment was conducted in a randomized block design where the treatments corresponded to nine microvinifications arranged in three replicates. The concentration of total polyphenols in Cabernet Sauvignon red wines is associated with anthocyanins, indices of absorbances of 420 and 520, as well as total acidity. However, the tannins are directly proportional to the total acidity of the wine. Environmental conditions with high rainfall, minimum oscillations in thermal amplitude and incident solar radiation tend to increase the hydrogenionic potential and the absorbance indices of 420 (yellow) and 620 (bluish) red wines of Cabernet Sauvignon. The thermal amplitude was preponderant to elevate levels of anthocyanins in Cabernet Sauvignon wines.
\end{abstract}

Keywords: enology, grape production, physicochemical traits

\section{Introduction}

The climatic aspects can determine the physical and chemical parameters of the wine, being these essential for the sensorial quality and shelf life in front of the consumer market (Zocche et al., 2017). In this context, Cabernet Sauvignon wines presented differences among the physical and chemical parameters due to the peculiar characteristics of the producing regions and climatic conditions (Zocche et al., 2016a). Thus, total acidity, anthocyanins, $\mathrm{pH}$, tannins and total polyphenols are determinant for sensory quality, maturation and aging of red wines (Flanzy, 2003; Zamora, 2003). The region of the Campanha Gaúcha is located in the south of the state of Rio Grande do Sul, Brazil, and stands out nationally due to its production of fine wines. Sinimbu (2015) reports that this region is responsible for a production of $31 \%$ of the total fine wines produced in Brazil. Among the cultivated varieties, Cabernet Sauvignon is a highlight that reveals great commercial appreciation and accounts for a high fraction of the wines produced in the region of Campanha Gaúcha, both elaborated for young wines and for aging. Research has defined that this variety is currently the most cultivated in the country (Giovannini, 2001; Zocche et al., 2016a, 2016b; Jacobs et al., 2016).

Cabernet Sauvignon has been subjected to detailed research in the Campanha region in the state of Rio Grande do Sul, Brazil, where Zocche et al. (2016a) and Jacobs (2016) measured the characteristics important for this variety and defined what would be the essential relations for the quality of the wine obtained. However, some criteria are relevant for the elaboration of quality wines, and it is necessary to understand the mechanisms that determine the physical and chemical parameters of these wines, evidencing the relationships and climatic attributes that can affect these parameters of importance. Research on Cabernet Sauvignon determined the influence of the peculiar characteristics of the growing environment on the physical and chemical characteristics of the grape (Barnuud et al., 2014). 
Among the important traits, anthocyanins directly influence the color of red wines, where their concentration oscillates according to the variety cultivated and the environment where it is inserted. However, the phenolic composition and the concentrations of some attributes vary due to the cultural practices, managements, microclimate and genetic characteristics of the variety (Downey et al., 2006). These phenotypic characters of importance are linked to the sensorial quality of the wine, and the concentration of these can aid in the selection of which will be the procedure applied in the production of aging or young wine. The sensorial peculiarities of wine are dependent on the magnitudes of the $\mathrm{pH}$ that determines the stability and precipitation of anthocyanins, this attribute when elevated entails in the instability and reduction of the concentration of anthocyanins in the wines (Zocche et al., 2016a), in the same way, these can be influenced by air temperature and incident solar radiation intensity (Soubeyrand et al., 2014).

The $\mathrm{pH}$ of the wines determines the sensory quality and shelf life of the product obtained, influences the microbiological stability, the color of the red wines, causes microbiological and physicochemical changes in the wine produced (Rizzon \& Miele, 2002). The color of wines is defined as one of the quality parameters for red wines. As a criterion, it is measured the absorbance spectra of 420,520 and 620 nanometers to represent the shades and intensity referring to the colors yellow, red and blue.

The tannins influence the sensorial quality in red wines through body characteristics, tactile sensations, astringency, in contrast, their excess can lead to pejorative definitions (Zamora, 2003). The tannins act fundamentally on the stability of the anthocyanins of red wines, and these can prevent the precipitation and the loss of coloration through the connections among them. The proanthocyanidins present in grape are characterized as polymers consisting of flavanols that protect wine from oxidation, increase flavor complexity and color stability. The presence of tannins with anthocyanins is sought, but for this to occur it is necessary for both to exhibit adequate concentrations and to be efficiently linked so that anthocyanins remain stable over time (Cheynier, 2005).

These characters are influenced by the processes of elaboration and climatic attributes, in this way, researches of Leão and Silva (2003) determined that the performance of the vines were based on the interaction genotypes $x$ growing environments, and the air temperature and rainfall were essential for the phenolic maturation of the grapes, however, the thermal amplitude determined the physical and chemical characteristics of the wine (Kishino \& Marur, 2007). Vines depend on climatic attributes for biosynthesis, translocation, degradation and accumulation of substances in the berries, and that these are transferable to wines and reflect on color, aroma, taste, body, acidity and structure (Zanus \& Tonietto, 2012). In this context, it is essential to understand the dynamics responsible for the quality of red wines. Thus, this work had the objective of revealing the physico-chemical and climatologic relationships that determine the quality of Cabernet Sauvignon wines.

\section{Material and Methods}

The experiment was carried out in the municipality of Dom Pedrito, Rio Grande do Sul, Brazil, in the agricultural crop of 2016. The grapes were harvested from the Cabernet Sauvignon variety and from a commercial vineyard located at Latitude: $31^{\circ} 01^{\prime} 20.031^{\prime \prime} \mathrm{S}$ and Longitude: $54^{\circ} 36^{\prime} 11.655^{\prime \prime} \mathrm{W}$, with a climate characterized as subtropical Cfa not very humid, with cold winter and mild summer, annual precipitation between 1200 and $1500 \mathrm{~mm}$ and average air temperature from 17 to $20{ }^{\circ} \mathrm{C}$, the soil is classified as Vertic Planosol of medium to clayey texture (IBGE, 2017a, 2017b; Rossato, 2011). The vineyard is composed of seedlings from the clone R5 and rootstock $\mathrm{SO} 4$, conducted in a trellis driving system, with two double mobile wires, spacing 1.25 meters $(\mathrm{m})$ between plants and $3 \mathrm{~m}$ between rows, pruning was performed in bilateral cordons in a vineyard of 2.5 hectares implanted since 1990.

The experiment was conducted in a randomized block design where the treatments corresponded to nine microvinifications arranged in three replicates. These were carried out in graduated glass bottles with a capacity of 20 liters. The grapes were harvested and stored in a cold chamber for 24 hours so that after, there could be performed manual destemming, addition of potassium metabisulphite at a dose of $100 \mathrm{mgL}^{-1}$ and in the sequence, a dose of $300 \mathrm{mg} \mathrm{L}^{-1}$ of yeasts Saccharomyces cerevisiae (Maurivin ${ }^{\circledR}$ PDM).

After 30 days of the end of the alcoholic fermentation the physical-chemical characteristics were measured, being these: hydrogenionic potential (HIP): measured in $\mathrm{pH}$ units (Ribéreau-Gayon et al., 1976); titratable total acidity (TTA): obtained by titrating in meq $\mathrm{L}^{-1}$ (Amerine and Ough, 1976); volatile acidity (VTA): obtained by titrating in meq $\mathrm{L}^{-1}$ (Amerine and Ough, 1976); tannins (TAN): expressed in $\mathrm{g} \mathrm{L}^{-1}$ (Ribéreau-Gayon \& Stonestreet, 1965); anthocyanins (ANT): expressed in $\mathrm{g} \mathrm{L}^{-1}$ (Ribéreau-Gayon \& Stonestreet, 1965); color indices 420 (420): expressed in units (Ribéreau-Gayon \& Stonestreet, 1965); color index 520 (520): expressed in units 
(Ribéreau-Gayon \& Stonestreet, 1965); color index 620 (620): expressed in units (Ribéreau-Gayon \& Stonestreet, 1965); total polyphenols index (TPI): expressed in $\mathrm{g} \mathrm{L}^{-1}$ (Ribéreau-Gayon \& Stonestreet, 1965).

The data were submitted to analysis of variance at $5 \%$ of probability where the homogeneity of variances was verified by the Bartlet test (Ramalho et al., 2012) and normality by Shapiro-Wilk (1969). Significant characters were submitted to linear correlation in order to reveal the trend of linear association among the measured characters. Afterwards, the stepwise multiple regression was performed, where the $\mathrm{pH}$, anthocyanins, color indexes of the absorbances of 420,520 and 620, total polyphenols index, tannins and total acidity in wine were determined as dependent characters, on the other hand, meteorological variables such as air temperature range, minimum and maximum air temperature, incident solar radiation and rainfall were considered as independent or explanatory characters of the predictor model.

\section{Results and Discussion}

The minimum and maximum air temperatures, rainfall and incident solar radiation are considered climatic attributes essential for the growth and development of the vines. In this way, the vineyard is located in an area that reveals annual average air temperatures from 17 to $20{ }^{\circ} \mathrm{C}$ and rainfall around 1200 to $1500 \mathrm{~mm}$ (Table 1). For the maturation of Cabernet Sauvignon, the minimum and maximum air temperatures required were above the average expected for the period of this study. On the other hand, rainfall levels were lower than the required by the crop. The mean physical-chemical parameters measured in the wine (Table 1) are outside the parameters required in the production of quality wine.

The hydrogenionic potential (HIP) was above the ideal defined for the production of wines. In this way, high magnitudes can result in instability in color, microbiological and red wine tonality. However, it is important to note that the magnitude of $\mathrm{pH}$ is determinant for the expression of anthocyanins, and their increase may result in oxidized shades, whereas their decrease results in red tones in the wine (Castañeda-Ovando et al., 2009; Heras-Roger, 2016). Several factors are related to $\mathrm{pH}$ magnitude, such as total acidity, potassium concentration and the proportions of tartaric and malic acids (Conde et al., 2007). The titratable total acidity (TTA) obtained was higher than the values recommended for the production of red wine, high magnitudes did not favor the $\mathrm{pH}$ reduction, this requires that detailed studies be elaborated to understand the dynamics of the acids contained in the wine during the processes of elaboration. The volatile acidity (VTA) evidenced that its magnitude is within the criteria established as optimal for the elaboration and conservation of red wines. Researches define that this character is a physical-chemical parameter measured throughout the process of wine elaboration, and the alcoholic fermentation occurs within the limits from 4 to $6 \mathrm{meq} \mathrm{L}^{-1}$ of volatile acidity (Ribérau-Gayon et al., 2003).

Table 1. Means of meteorological indices and physico-chemical parameters of Cabernet Sauvignon wines, in the municipality of Dom Pedrito, RS, crop 2016

\begin{tabular}{ll}
\hline Variable & Means \\
\hline Maximum temperature $\left({ }^{\circ} \mathrm{C}\right)$ & 30.269 \\
Minimum temperature $\left({ }^{\circ} \mathrm{C}\right)$ & 20.126 \\
Radiation $\left(\mathrm{kJ} / \mathrm{m}^{2}\right)$ & 1874 \\
Precipitation $(\mathrm{mm})$ & 2.043 \\
Amplitude $\left({ }^{\circ} \mathrm{C}\right)$ & 10.143 \\
\hline $\mathrm{pH}$ & 3.880 \\
Total acidity $\left(\mathrm{meq} \mathrm{L}^{-1}\right)$ & 131.611 \\
Volatile acidity $\left(\mathrm{meq} \mathrm{L}^{-1}\right)$ & 4.757 \\
Tannins $\left(\mathrm{g} \mathrm{L}^{-1}\right)$ & 1.287 \\
Anthocyanins $\left(\mathrm{mg} \mathrm{L}^{-1}\right)$ & 308.116 \\
DO 420 & 0.275 \\
DO 520 & 0.385 \\
DO 620 & 0.071 \\
Tonality $(420 / 520)$ & 0.741 \\
TPI $(\mathrm{g} \mathrm{L}-1)$ & 34.122 \\
\hline
\end{tabular}


The tannins were lower than the desired magnitude of $2 \mathrm{~g} \mathrm{~L}^{-1}$, these limits define the elaboration of quality wines (Zamora, 2003). Tannins are responsible for tactile sensations such as astringency, bitterness and structure of wine (Flanzy, 2003; Zamora, 2003). Anthocyanins (ANT) were lower than the desired amount of $400 \mathrm{mg} \mathrm{L}^{-1}$ (Zamora, 2003). The concentration of anthocyanins and the $\mathrm{pH}$ that define wine quality are dependent on the intrinsic genetic characteristics of the genotype used and the growing environment (Castañeda-Ovando et al., 2009; Zocche, 2016a). Regarding the characters related to the color of the wine (absorbance indexes of 420,520 and 620 nanometers), it was observed that the wine tonality was close to 1.0 indicating the great evidence of the yellow color present in the wine, that is due to the expression of the wines reddish-brown tonalities. Research has shown that Cabernet Sauvignon wines produced in Campanha resulted in similar tonalities (Zocche et al., 2016a). These effects were derived from the dynamics expressed by the magnitude of the $\mathrm{pH}$ and oxidation processes of the wine (Castañeda-Ovando et al., 2009). The total polyphenols were less than $40 \mathrm{~g} \mathrm{~L}^{-1}$, which was defined as adequate in the elaboration of red wine (Zamora, 2003). For the production of quality wines, the $\mathrm{pH}$, total acidity, anthocyanins, tannins, and total polyphenols are important for phenolic maturation and adequate wine aging (Flanzy, 2003; Zamora, 2003).

The characters hydrogenionic potential (HIP), titratable total acidity (TTA), volatile acidity (VTA), tannins (TAN), anthocyanins (ANT), color indices 420 (420), color index 520 (520), color index 620 (620) and total polyphenols index (TPI) revealed significance at $5 \%$ of probability by the $t$ test, in this way, all the characters were submitted to linear correlation analysis in order to identify the tendency of association among the characters of interest (Table 2), together, it was correlated the climatic attributes maximum air temperature (MXT), minimum air temperature (MNT), incident solar radiation (RAD), rainfall precipitation (PRE) and air temperature range (RAN). There were performed 78 linear associations, and only 15 of these relations were significant at $5 \%$ of probability by the t-test.

Table 2. Pearson correlation between meteorological variables and physicochemical arameters of Dom Pedrito Cabernet Sauvignon wine, RS, 2016 crop

\begin{tabular}{|c|c|c|c|c|c|c|c|c|c|c|c|c|c|}
\hline & TPI & HIP & TTA & TAN & ANT & 420 & 520 & 620 & MXT & MNT & RAD & PRE & RAN \\
\hline TPI & 1.00 & $-0.76^{*}$ & $0.70^{*}$ & 0.56 & $0.83 * *$ & $0.83 * *$ & $0.88 * *$ & 0.61 & 0.44 & 0.44 & 0.18 & 0.18 & 0.33 \\
\hline HIP & & 1.00 & $-0.97 * *$ & -0.60 & $-0.96 * *$ & -0.39 & -0.59 & -0.06 & -0.14 & -0.09 & -0.36 & 0.01 & -0.39 \\
\hline TTA & & & 1.00 & $0.69^{*}$ & $0.94 * *$ & 0.54 & $0.71 *$ & 0.10 & 0.07 & -0.01 & 0.21 & -0.04 & 0.30 \\
\hline TAN & & & & 1.00 & $0.69^{*}$ & 0.35 & 0.43 & 0.16 & 0.15 & 0.18 & -0.16 & -0.35 & 0.23 \\
\hline ANT & & & & & 1.00 & 0.54 & $0.71^{*}$ & 0.23 & 0.08 & 0.05 & 0.18 & -0.05 & 0.41 \\
\hline 420 & & & & & & 1.00 & $0.96^{* *}$ & $0.94 * *$ & 0.29 & 0.31 & -0.27 & 0.32 & 0.26 \\
\hline 520 & & & & & & & 1.00 & $0.83 * *$ & 0.24 & 0.21 & -0.17 & 0.31 & 0.36 \\
\hline 620 & & & & & & & & 1.00 & 0.23 & 0.27 & -0.45 & 0.33 & 0.14 \\
\hline MXT & & & & & & & & & 1.00 & $0.95^{* *}$ & 0.53 & 0.27 & -0.17 \\
\hline MNT & & & & & & & & & & 1.00 & 0.44 & 0.11 & -0.12 \\
\hline RAD & & & & & & & & & & & 1.00 & 0.18 & -0.04 \\
\hline PRE & & & & & & & & & & & & 1.0 & 0.41 \\
\hline RAN & & & & & & & & & & & & & 1.00 \\
\hline
\end{tabular}

Note. **, * Significant at 1 and $5 \%$ of probability by $\mathrm{t}$ test.

TPI: total polyphenols index; HIP: hydrogenionic potential; TTA: titratable total acidity; TAN: tannins; ANT: anthocyanins; MXT: maximum air temperature; MNT: minimum air temperature; RAD: radiation; PRE: precipitation; RAN: air temperature range.

$\mathrm{N}$ : 36 experimental samples.

The hydrogenionic potential (HIP) showed an inverse association with total polyphenols (TPI), anthocyanins (ANT) and total acidity (TTA). In this context, the reduction of the hydrogenionic potential of the wine results in an increase in the concentration of total polyphenols and changes in the concentration of anthocyanins, stability in wine coloring, as well as greater evidence of tartaric and malic acids, essential components for the total acidity of the wine (Ribéreau-Gayon, 2003).

Total acidity (TTA) was positively associated with anthocyanins (ANT), tannins (TAN) and total polyphenols (TPI). Therefore, the concentration of extracted anthocyanins, total tannins and polyphenols may be associated 
with the total acidity (TTA) of the wine. Acidic media may contribute to the expression and extraction of these compounds from the berry by disrupting the film cells. Total acidity was positively associated with the color index 520 (520) character, in this way, it is evident that the anthocyanins were determinants for the red color expression in wines, since they potentiate the presence of flavilium cation in the $\mathrm{A}+$ form (Zamora, 2003).

Total polyphenols (TPI) were associated with anthocyanins (ANT) and color index 520 (520). This dynamics occurred due to the anthocyanins composing the scope of the total polyphenols (TPI) and being closely related to the red coloration of the wine. There was a positive correlation between the concentration of tannins (ANT) and anthocyanins (ANT) present in wine, in this way, the synthesis and extraction of anthocyanins occurs through the film of the berries, which enable them to obtain anthocyanins and extract tannins during the winemaking processes.

The color index of 420 (420) was positively associated with total polyphenols (TPI) and color indices 520 (520) and 620 (620). Thus, the increase of the colorimetric fraction of red (520) and blue (620) results in the direct increase of the yellow fraction (420), this occurs due to the oxidative processes occurring on darker spectra (520 and 620), physical-chemical changes and changes in $\mathrm{pH}$ magnitude. In this way, it is sought to potentiate the absorbance spectra (520 and 620) to result in increased hue, as well as to improve the color quality of red wines. Through the linear correlations it was not possible to identify any significant linear association between the climatic attributes and those focused on the quality of the wine, of these conditions, it is assumed that a multivariate dynamics should be considered for the explicability of each character that confers quality to the wine.

A predictor model was established through Stepwise multiple regression for each wine quality character, under these conditions the characters $\mathrm{pH}$, anthocyanins, color indices were measured at the absorbances of 420,520 and 620 , total polyphenols index, tannins and total acidity being considered as dependent, in contrast, the air temperature range, minimum and maximum air temperature, incident solar radiation and rainfall were considered as explanatory for the predictor model (Table 3 ). The predictive models showed a coefficient of determination $\left(\mathrm{R}^{2}\right)$ intermediate to high values of 0.41 and 0.89 , which gave high accuracy of the predictive model of wine quality determined by the climatologic attributes.

Table 3. Step wise predicted model for qualitative parameters of Cabernet Sauvignon wines from Dom Pedrito, RS, crop 2016

\begin{tabular}{lll}
\hline & Predicted model & $\mathbf{R}^{2}$ \\
\hline HIP & $4.18861-0.00013200 \cdot \mathrm{RAD}+0.00848 \cdot \mathrm{PRE}-0.10125 \cdot \mathrm{AMP}$ & 0,61 \\
ANT & $261.83100+44.58166 \cdot \mathrm{AMP}$ & 0.41 \\
DO 420 & $-0.05845+0.01923 \cdot \mathrm{TMN}-0.00008683 \cdot \mathrm{RAD}+0.00497 \cdot \mathrm{PRE}$ & 0,66 \\
DO 520 & $-0.12428+0.02827 \cdot \mathrm{TMX}-0.00015179 \cdot \mathrm{RAD}+0.1434 \cdot \mathrm{AMP}$ & 0.61 \\
DO 620 & $0.03293+0.00445 \cdot \mathrm{TMX}-0.00004171 \cdot \mathrm{RAD}+0.00146 \cdot \mathrm{PRE}$ & 0.79 \\
TPI & $2.98972+1.17003 \cdot \mathrm{TMN}+2.45465 \cdot \mathrm{AMP}$ & 0.59 \\
TAN & $3.9487+0.50807 \cdot \mathrm{TMX}-0.57767 \cdot \mathrm{TMN}-0.00060873 \cdot \mathrm{RAD}-0.12663 \cdot \mathrm{PRE}+0.70871 \cdot \mathrm{AMP}$ & 0.89 \\
TTA & $85.13047+6.99842 \cdot \mathrm{TMX}-7.73215 \cdot \mathrm{TMN}+0.03124 \cdot \mathrm{RAD}-4.26697 \cdot \mathrm{PRE}$ & 0.48 \\
\hline
\end{tabular}

Note. HIP: hydrogenionic potential; ANT: anthocyanins; TPI: total polyphenols index; TAN: tannins; TTA: titratable total acidity; RAD: radiation; PRE: precipitation; MNT: minimum air temperature; MXT: maximum air temperature; RAN: air temperature range.

The predictive model for the hydrogenionic potential (HIP) was determined by the reduction of the thermal amplitude and photosynthetically active radiation, in contrast to an increase in rainfall (Table 3). The increase of the $\mathrm{pH}$ of the wine occurs when the plants are cultivated in environments with high precipitation, in the same way, they reveal smaller intencities of incident radiation with minimum oscillations of the air temperature. Research has shown that the increase in $\mathrm{pH}$ was due to the higher concentration of malic acid in the berries, water supply to plants and availability of nutrients mainly of potassium (Kliewer, 1967; Johson \& Nagel, 1976). Anthocyanins (ANT) are influenced by a higher thermal amplitude gradient of the air, these results are confirmed by Ubalde (2010), who determined the synthesis of anthocyanins in Cabernet Sauvignon, being higher in harvests or seasons of the year when the air temperature range was higher. The air amplitude corresponds to the interval between the maximum and minimum thermal temperatures, which are closely related 
to the synthesis of the anthocyanins, therefore it is defined that air temperatures above $35{ }^{\circ} \mathrm{C}$ decrease the accumulation of anthocyanins in the berries (Cheng et al., 2014).

The absorbance index for color 420 (420) represents the yellow tones and the index of 620 (620) represents the bluish tones in wines, these characters were represented by a predictor model determined by the increment of rainfall, minimum temperature to 420 (420) and maximum temperature for 620 (620), in contrast, less emphasis on incident solar radiation. Due to this, wines that show yellowish and blue tones can be obtained when minimum and maximum air temperatures and high accumulated precipitation are obtained, however the solar radiation on the canopy is reduced. The 520 (520) index was determined by increasing the maximum air temperature and the thermal amplitude, with reduction of incident solar radiation, this character is shown to be directly dependent on higher air temperatures. Researches define that the absorbance indices in wines are directly influenced by the climatological attributes (Ubalde, 2010).

Total polyphenols (TPI) were determined by raising the minimum air temperature and thermal amplitude. Cabernet Sauvignon red wines are directly influenced by climatological attributes (Ubalde, 2010). The concentration of tannins (TAN) in wine was defined by maximum air temperatures and higher thermal amplitudes, in contrast, lower effects of incident solar radiation and rainfall. Research has shown that the phenolic compounds of the wine are determined by the enzymatic activity of the phenylalanine ammonia-lyase (PAL), which is dependent on the quality and light intensity, as well as on the incident radiation balance (Dias et al., 2015).

The total acidity (TTA) was determined by the increase of the maximum air temperature, incident solar radiation, however, smaller effects are obtained through minimum air temperature and rainfall. This dynamics can influence the photosynthetic process and absorption of nutrients by the grapevine, mainly absorption and translocation of potassium characterized with a macronutrient determining to the magnitude of the total acidity. These predictive models made it possible to understand the climatic attributes determining the characteristics of the Cabernet Sauvignon red wines. The understanding of this dynamics allows to increase the biological explanation about the elaboration of red wines in the region of Campanha, Rio Grande do Sul.

\section{Conclusion}

The concentration of total polyphenols in Cabernet Sauvignon red wines is associated with anthocyanins, indices of absorbances of 420 and 520, as well as total acidity. However, the tannins are directly proportional to the total acidity of the wine.Environmental conditions with high rainfall, minimum oscillations in thermal amplitude and incident solar radiation tend to increase the hydrogenionic potential and the absorbance indices of 420 (yellow) and 620 (bluish) red wines of Cabernet Sauvignon.The thermal amplitude was preponderant to elevate levels of anthocyanins in Cabernet Sauvignon wines.

\section{References}

Amerine, M. A., \& Ough, C. S. (1976). Análisis de vinos y mostos. Zaragoza: Acríbia.

Barnuud, N. N., Zerihun, A., Gibberd, M., \& Bates, B. (2014). Berry composition and climate: responses and empirical models. International Journal of Biometeorology, 58(6), 1207-1223. https://doi.org/10.1007/ s00484-013-0715-2

Castañeda-Ovando, A., Pacheco-Hernández, M. L., Páez-Hernández, M. E., Rodríguez, J. A., \& Galán-Vidal, C. (2009). Chemical studies of anthocyanins: A review. Food Chemistry, 113(4), 859-871. https://doi.org/ 10.1016/j.foodchem.2008.09.001

Cheng, G., He, Y. N., Yue, T. X., Wang, J., \& Zhang, Z. W. (2014). Effects of climatic conditions and soil properties on Cabernet Sauvignon berry growth and anthocyanin profiles. Molecules, 19(9), 13683-13703. https://doi.org/10.3390/molecules190913683

Cheynier, V. (2005). Polyphenols in foods are more complex than often thought. American Journal of Clinical Nutrition, 81(1), 223-229. https://doi.org/10.1093/ajen/81.1.223S

Conde, C., Silva, P., Fontes, N., Dias, A. C. P., Tavares, R. M., Sousa, M. J., ... Gerós, H. (2007). Biochemical changes throughout grape berry development and fruit and wine quality. Food, 1, 1-22.

Dias, T., De Mello, H. C., Alves, F. R. R., Carvalho, R. F., Carneiro, K. S., \& Souza, C. M. (2015). Compostos fenólicos e a capacidade antioxidante em frutos de tomateiros mutantes fotomorfogenéticos. Ciência Rural, 45(5), 782-787. https://doi.org/10.1590/0103-8478cr20140098 
Downey, M. O., Dokoozlian, N. K., \& Krstic, M. (2006). Cultural practice and environmental impacts on the flavonoid composition of grapes and wine: A review of recent research. American Journal of Enology and Viticulture, 57(3), 257-268.

Flanzy, C. (2003). Enología: Fundamentos científicos y tecnológicos. Madrid: Mundi-Prensa.

Giovannini, E. (2001). Cultivares. In E. Giovannini (Ed.), Uva agroecológica (pp. 76-80). Porto Alegre: Renascença.

Heras-Roger, J., Alonso-Alonso, O., Gallo-Montesdeoca, A., Díaz-Romero, C., \& Darias-Martín, J. (2016). Influence of copigmentation and phenolic composition in wine color. Food Chemistry, 197, 39-46. https://doi.org/10.1007/s13197-016-2210-3

IBGE (Instituto Brasileiro de Geografia e Estatística). (2017a). Mapa exploratório de solos do estado do Rio Grande do Sul. Retrieved June 15, 2017, from ftp://geoftp.ibge.gov.br/informacoes_ambientais/pedologia/ mapas/unidades_da_federacao/rs_pedologia.pdf

IBGE (Instituto Brasileiro de Geografia e Estatística). (2017b). Banco de dados geodésicos. Retrieved June 15, 2017, from http://www.ibge.gov.br/home/geociencias/geodesia/bdgpesq_googlemaps.php

Jacobs, S. A., Zocche, R. G. S., Jacobs, B., Zocche, F., Sampaio, N. V., Rizzon, L. A., ... Rombaldi, C. V. (2016). Behavior oh phenolic and color parameters during grape vinification of Tannat and Cabernet Sauvignon cvs. in Bagé-RS. International Journal of Current Research, 8(7), 34863-34867.

Johnson, T., \& Nagel, C. W. (1976). Composition of Central Washington grapes during maturation. American Journal Enology and Viticulture, 27(1), 15-20.

Kishino, A. Y., \& Marur, I. P. H. (2007). Fatores climáticos e o desenvolvimento da videira. In A. Y. Kishino, S. L. C. Carvalho, \& S. R. Roberto (Eds.), Viticultura tropical (pp. 59-86). Londrina: IAPAR.

Kliewer, W. M., Howarth, L., \& Omori, M. (1967). Concentrations of tartaric acid, malic acid and their salts in Vitisvinifera grapes. American Journal of Enology and Viticulture, 18(1), $42-54$.

Leão, P. C. S., \& Silva, E. E. G. (2003). Phenological evaluation and thermal requirements of five seedless grapes in the San Francisco river valley. Revista Brasileira de Fruticultura, 25(3), $379-382$. https://doi.org/10.1590/S0100-29452003000300004

Ramalho, M., Santos, J. B., Pinto, C. B., Souza, E. A., Gonçalves, F. M. A., \& Souza, J. C. (2012). Genetics in agriculture (p. 566). Lavras, Brazil.

Ribérau-Gayon, P., Glories, Y., Maujean, A., \& Dubourdieu, D. (2003). Tratado de Enologia: Quimica del vino, estabilización y tratamentos (p. 537). Buenos Aires: Hemisfério Sur.

Ribéreau-Gayon, P., \& Stonestreet, E. (1965). Dosage des anthocyanes dans les vines rouge. Bulletin de la Societé Chimique de France, 9, 2649-2652.

Rizzon, L. A., \& Miele, A. (2002). Evaluation of the cv. Cabernet Sauvignon in the manufacture of red wine. Ciência e Tecnologia de Alimentos, 22(2), 192-198. https://doi.org/10.1590/S0101-20612002000200015

Rossato, M. S. (2011). Os climas do Rio Grande do Sul: Variabilidade, tendências e tipologia [p. 240, Tese (Doutorado). Universidade Federal do Rio Grande do Sul].

Shapiro, S. S., \& Wilk, M. B. (1965). An analysis of variance test for normality (Complete Samples). Biometrika, 52(3/4), 591-611. https://doi.org/10.1093/biomet/52.3-4.591

Sinimbu, F. (2017). Cientistas ajudam Campanha Gaúcha a obter selo de procedência para vinhos. Retrieved June 15, 2017, from https://www.embrapa.br/busca-de-noticias/-/noticia/6031942/cientistas-ajudam-campa nha-gaucha-a-obter-selo-de-procedencia-para-vinhos

Soubeyrand, E., Basteau, C., Hilbert, G., Van Leeuwen, C., Delrot, S., \& Gomès, E. (2014). Nitrogen supply affects anthocyanin biosynthetic and regulatory genes in grapevine cv. Cabernet Sauvignon berries. Phytochemistry, 103, 38-49. https://doi.org/10.1016/j.phytochem.2014.03.024

Ubalde, J. M., Sort, X., Alicia Zayas, A., \& Poch, R. M. (2010). Effects of soil and climatic conditions on grape ripening and wine quality of Cabernet Sauvignon. Journal of Wine Research, 21, 1-17. https://doi.org/ 10.1080/09571264.2010.495851

Zamora, F. (2003). Elaboración y crianza del vino tinto: Aspectos científicos y práticos (p. 225). Madrid: Mundi-Prensa. 
Zanus, M. C., \& Tonietto, J. (2012). Elementos metodológicos para a caracterização sensorial de vinhos de regiões climáticas vitivinícolas. In J. Tonietto, V. S. Ruiz, \& V. D. Gómez-Miguel (Eds.), Clima zonificación y tipicidade del vino em regiones vitivinícolas iberoamericanas (pp. 39-46). Cyted: Madrid.

Zocche, R. G. S., Jacobs, S. A., Sampaio, N. V., Souza, V. Q., Carvalho, I. R., Nardino, M., ... Rombaldi, C. V. (2017). Wines produced with 'Cabernet Sauvignon' grapes from the region of Bagé in the state of Rio Grande do Sul, Brazil. Pesquisa Agropecuaria Brasileira, 52(6), 311-318. https://oi.org/10.1590/ s0100-204x2017000500004

Zocche, R. G. S., Jacobs, S. A., Souza, V. Q., Nardino, M., Carvalho, I. R., Rombaldi, C. V., ... Rizzon, L. A. (2016a). Wine characterization from Merlot, Tannat and Cabernet Sauvignon grapes of the Campanha Region of RS, harvested in two maturation stages. International Journal of Current Research, 8(6), 33078-33086.

Zocche, R. G. S., Jacobs, S. A., Souza, V. Q., Nardino, M., Carvalho, I. R., Rombaldi, C. V., ... Rizzon, L. A. (2016b). Characterization of Cabernet Sauvignon wine made with grapes from Campanha RS Region. African Journal of Agricultural Research, 11(42), 4262-4268. https://doi.org/10.5897/AJAR2016.11076

\section{Copyrights}

Copyright for this article is retained by the author (s), with first publication rights granted to the journal.

This is an open-access article distributed under the terms and conditions of the Creative Commons Attribution license (http://creativecommons.org/licenses/by/4.0/). 